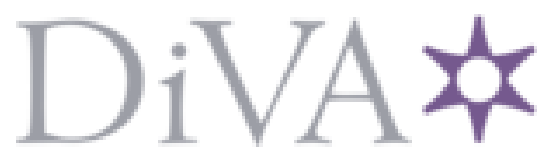

http://www.diva-portal.org

This is the published version of a chapter published in Urban Planet : Knowledge Towards Sustainable Cities.

Citation for the original published chapter:

Parnell, S., Elmqvist, T., McPhearson, T., Nagendra, H., Sörlin, S. (2018)

Introduction: Situating knowledge and action for an urban planet

In: Thomas Elmqvist, Xuemei Bai, Niki Frantzeskaki, Corrie Griffith, David Maddox,

Timon McPhearson, Susan Parnell, Debra Roberts, Patricia Romero-Lankao, David

Simon, and Mark Watkins (ed.), Urban Planet : Knowledge Towards Sustainable

Cities (pp. 1-16). Cambridge: Cambridge University Press

https://doi.org/10.1017/9781316647554.002

N.B. When citing this work, cite the original published chapter.

Permanent link to this version:

http://urn.kb.se/resolve?urn=urn:nbn:se:kth:diva-233029 


\title{
Introduction: Situating Knowledge and Action for an Urban Planet
}

\author{
Susan Parnell, Thomas Elmqvist, Timon McPhearson, \\ Harini Nagendra, and Sverker Sörlin
}

The shared acceptance that we now live in a majority urban world and that cities will surely determine our future does not mean we agree on why or how the urban age is important. The Urban Planet thus draws from diverse intellectual traditions to grapple with the conceptual and operational challenges of sustainable urban development. The purpose of this book is to foster a community of global urban leaders through engaging the emerging science of cities and some of its critiques. The aspiration is that by generating ideas about global urbanism that situate the city at the core of the planet's future, we will provide pathways for evidence-based interventions to ensure ambitious changes. This is a significant undertaking (with over 100 contributors from urbanists drawn from both outside and inside the academy). The project on which this book is based is important because, over the next 30 years, based on population growth, the urbanization process will both accelerate and consolidate to make cities and towns, particularly settlements of the global south, an ever more dominant form of twenty-first-century human settlement. Moreover, this generation of scholars now finds itself responsible for producing the new information and analysis necessary to feed the innovation that will be required to make cities the most safe, resilient, equitable, and sustainable way of living.

Much of what happens across the global urban system will be down to citizens, political decision-makers, and the appropriateness of the institutions (including but not limited to states) on which we depend to manage ourselves and our environment. To meet the challenges that lie ahead, we argue that revisionist modes of urban knowledge and practice are imperative: Producing this requires an excitement and curiosity about cities to fuel a massive scaling up of our collective wisdom about the urban world we inhabit.

In setting the course for this volume, this chapter thus departs from the conventional format of an introduction that provides a summary or roadmap of the book. Note that such an overview of chapters is provided in the Preface, and the concluding chapter ("Synthesis") provides a review of 
the main points and details recurring, highlighting significant points that emerge from the book as a whole. Here we highlight four overarching points of departure in an effort to bring disparate readers into a common frame of reference from which they can engage with The Urban Planet. First, we reflect on what exactly is meant by "the urban," as this is the common but not universally understood object with which the chapters all grapple. Second, we locate the recent call among urban scholars (Acuto and Parnell 2016; Bai et al. 2017; McPhearson et al. 2016a; Batty 2013) for greater attention to be given to building a science of cities in historical context by exploring the importance of urbanism in the evolution of science and critical urban theory, here using the example of urban natures. Third, we underscore twin imperatives for the future science of cities: the increasing impacts of cities in global change and the southern concentration of urbanization - noting how attention to speed and geography must prioritize the focus of global urban inquiry (McPhearson et al. 2016b). Fourth and finally, we foreground the tensions of working across disciplinary boundaries and methods, and concede the tensions inherent in coproducing urban knowledge. However, these preparatory points, about defining the urban, the imperative of being mindful of history and geography and the possibly insurmountable dilemmas of coproduction, and inter-/transdisciplinarity should stimulate and not detract in any way from the urgency of galvanizing research capacity to advance the understanding of the urban planet.

\subsection{What Is Urban?}

Given the consensus that this is an urban age and that cities present both critical opportunities and threats for a common future, it is perhaps surprising that there is so little agreement on what constitutes or defines "the urban." This is an immensely challenging question with no simple answer, and the approaches taken in social and natural sciences to global urbanism have only limited concerns (Parnell and Robinson 2017). There is a surprising lack of common understanding even among scientific disciplines on what characterizes or defines an urban area or urbanization, making comparative and composite assessments of urban change difficult. To underscore the obvious - while it is accepted that there is a common urban future which will in large part determine the state of the urban planet - there is neither a shared definition of "the urban" nor an agreement on city experiences or forms from which to engage or predict the outcomes of our urban futures (Robinson 2016; Simon 2016; Mitlin and Sattherthwaite 2013). This diversity of perspective and definition is understandably also reflected in the chapters of The Urban Planet. 
As discussed in many of the following chapters, there are multiple dimensions to urbanity. Different perspectives or big ideas that are brought to bear on our core research issue include not just meta-theoretical differences but overlapping, competing, and even disparate research entry points. In positive terms, these varied conceptual and methodological points of departure highlight different ideologies and interests. They also encompass research on multiple elements of the urban - reflecting the diverse specialties of scholars from natural systems science, the design profession and economics (McPhearson et al. 2016a; Bai et al. 2017). But, not least because of this diversity of entry points, incommensurability remains a problem for urban science and comparative urbanism, and a central objective of the book is to address the need to accommodate the range of scholarly perspectives and to suggest how we may proceed to somehow make these speak to each other, thereby crafting a new and deeper holistic understanding of global urban processes. The common themes provide a starting point for presenting global urbanization as a story of great diversity, but perhaps we should count on diversity in solutions and modes of progress too. Variation in specific city experience should, however, not detract from the impact of the amalgamation of urban development on global change; and there is no doubt that, while the evolving science of cities will always need to grapple with the wicked problem of specificity, it must simultaneously generate if not a universal narrative but at least a comprehensive understanding of the complexities of urban change.

The current impetus to give greater weight to cities in general derives in large part from the massive expansion of the urban population over the last century and in part from the argument that an urban or industrial way of life has profoundly ruptured the geological and climate change in the earth system. It is, however, naive to regard the process of global urbanization as a unified or unidirectional phenomenon. Rather, in making the case that the urban is an important determinant of environmental, political, or social change, it helps to look back as well as forward. It is also helpful to interrogate more than demographic and biophysical evidence and to consider the impacts of the rise of the city and urbanism over the last 200 years as a plural, albeit of course very massive, historical phenomenon.

The Anthropocene narrative in this is both useful and obfuscating. It has unifying, sometimes also (suggestive) simplifying, storylines that tend to draw attention away from the diversity of human conditions (Biermann et al. 2016). Still, it suggests many key issues, and it lays out the land nicely with tons of "technofossil" data. Just consider the fact (Zalasiewicz et al. 2017) that, out of the 30 trillion tons of human materiality produced, cities account for (weigh, literally) 11 trillion tons, or 36 percent. Imagining the sheer scale of the urban is hard. In the late part of this century, one city, Dhaka, is projected to have 
80 million people. That is one Germany. Our conventional language breaks down in the face of such massive numbers, perhaps our politics, too. The challenges are obvious, but there is also a potential in the growth of cities. Cities are increasingly becoming regional and even global actors in their own right, either alone or in shaping alliances with other cities. Knowing the number of people in Dhaka is of course a limited frame of understanding. We need to compare, for instance, the consumption footprint of Dhaka versus Germany to understand this better. The Anthropocene is a compelling heuristic, but we need more and sharper analytical instruments in approaching the urban. In this, we would do well to consider the urban analytics of the past, as well as to develop new analytics of the future that engage more deeply with normative concerns and science.

\subsection{The Global Frame of Urbanism and a Science of Cities}

In the current notion of "planetary urbanism," Brenner and Schmid (2014) argue that urbanism is now the celebrated form of development (Florida 2002) that is recognized as a triumphal force for economic growth (Glaeser 2011). However, there is a long history of planetary urbanism, where cities have been centers of innovation and economic growth and have been driving formation of global trade networks and spread of ideas, technology, and capital for more than 4,000 years (Clark 2016). As the importance of cities is once again on the rise, there is a sense we may return to the power dynamics of the Middle Ages. Now, as then, how cities are run in this century may determine much of the world's future. Now, as then, the shifting role of cities in global change cannot be uncoupled from the way nature and ecologies are present in those urban developments and the connections between urban places (Clark 2016).

While there are many threads through which the history of cities and civilization are intertwined - political, economic, and social - the urban experience is also an experience of nature and environment. Cities belong in nature, having grown to be the largest environmental actor, indeed the sole creature of humanity that is most comprehensively entangled with the natural world paradoxically since the city was also meant to be the exception from nature, a civitas where the rules of nature did not apply or at least were tempered. The city was, it was once thought, what nature was not (Elmqvist et al. 2013). Nature for a long time had mostly an emblematic role in the description of the urban. In the historiography of cities, gardens and other forms of nature play their distinct role. Nature also appears in the history of urban infrastructures, 
such as waterways and sewage systems, and it is visible in utopian design ideals such as garden cities and suburbia, and dystopian narratives of diseases and disaster associated with urban infrastructure failure.

Research across a wide set of disciplines in recent years is now questioning the old dichotomy of a well or poorly managed split or interface between the city and nature (e.g. Melosi 1993 2010; Rosen and Tarr 1994; Sedrez 2005; Sharan 2014; Braun 2005; Heynen, Kaika, and Swyngedouw 2006; Gandy 2013). The growth of cities and their contribution to climate change (Rosenzweig et al. 2010) or health (Hodson 2016) is a good reason to stop keeping urban nature and culture apart. While the well-documented role of cities in driving climate change is widely acknowledged, less is known of other relationships between cities and other earth systems. Botanists and ecologists in European cities from the 1930s carried out early work on urban ecological interactions, but the roots of the study of urban botany go back to early modern times (Sukopp 2002). The most comprehensive work was carried out by a group led by Herbert Sukopp in West Berlin in the 1950s. They studied the return of vegetation to the war-torn urban landscape and found a fascinating array of new vegetation combinations (Lachmund 2011). Since the 1970s there has been a steadily growing interest in urban ecology that matured in the 1990s and now has its own established field with textbooks and journals (Elmqvist et al. 2013). Some of the major hubs in this line of work are in Europe (Helsinki, Stockholm) but there are concentrations in Australia (Melbourne), South Africa (Cape Town), China (Beijing), and India (Bangalore). In the United States, the movement was largely led by Baltimore and Phoenix, where long-term ecological research sites were established with funding from the National Science Foundation that saw a global scaling of traditionally anti-urban scientists in tracking cities.

Scholars' deep roots in the natural sciences marked the rise of urban sites in observational ecology. There was little interest in societal conflicts and how power relations shape urban ecologies, an interest that has been growing only recently (Ernstson and Sörlin 2018). It seems obvious that future research on the urban must better learn how to combine systems approaches with analysis of social and political dimensions, or at least work across those boundaries. There is already a rich, and indeed older, literature on social conflicts, class, race, and gender that could be of use for more synthetic approaches, but that literature on the other hand took marginal interest in nature until the appearance of works such as William Cronon's Nature's Metropolis: Chicago and the Great West (1991) or Erik Swyngedouw's $(1996,2004)$ on water, power, and the city.

Borrowing from human ecology and metabolic understandings of urban processes, much recent work has analyzed water, waste, sewage, electricity, and other substances/energies as "sociomaterial flows" with their own 
biophysical properties and "social relations," playing a role in the circulation of capital, upholding social structures, and producing often unequal urban environments (Warren-Rhodes and Koening 2001; Heynen et al. 2006; Bai et al. 2017. As has been argued in the most recent work on comparative global, and especially southern urbanism (Ernstson et al. 2014; Erixon Aalto and Ernstson 2017; Ernstson and Sörlin 2018), the concept of urban nature has become a much more complex phenomenon. Urban natures are now linking research to achieve ecological sustainability with critical studies and strategies for justice and equality in cities, as inseparable processes. In this regard, the situation for a building a complex knowledge of the urban experience, politics, and its future sustainability has greatly improved: for example, a new project called "cosmopolitics," about learning with nonhumans, focuses on how to live in cohabitation (Hinchliffe 2008; Hinchliffe and Whatmore 2006; Biehler 2011).

As Ernstson and Sörlin (2018) suggest in their review of the literature, it was in earnest only after 2000, after a slow and winding build-up period in the late twentieth century, that an "accidental discovery" of urban nature took place. To this discovery, all these and many other strands of academic work and practice contributed with their various pieces of the whole. However, they were almost invariably working in exclusive separation from each other and with quite little interest in bridging across scientific specialties. What remains is therefore, to a large extent, to bring the various research communities on the urban in closer and long-term relations with each other to spare no effort in carving roads forward for the major global challenge, and opportunity, that is urban growth.

One lasting finding found the new critical urban natures approaches and in the parallel body of critical urban studies is that diversity is an overarching theme that cannot be ignored in the global generalization or universalizing (Parnell and Robinson, 2017). While there is endless diversity, the urban planet is also unified by a set of mega-challenges, some of which are truly global, such as climate. Others are omnipresent without being global, such as justice, wealth, welfare, and sustainability. These mega-challenges may have local expressions, but they require national, regional, and international collaboration to be adequately addressed. No city is an island; they are all parts of the main. Our knowledge of the whole is patchy, and, crucially, we know least about those parts of the urban planet where change is occurring most rapidly and where the urban crisis is most acute, reinforcing the need for knowledge holders to reorient their view on global urbanism and to self-consciously try to "see cities from the south" (Watson 2009). 


\subsection{Cities of the Global South Are a Priority}

The global urban condition is not a composite of equivalent types or parts - all cities are not the same - in size, in function in wealth or in exposure to risk. In the remaining decades of the twenty-first century, projections indicate that most of the growth (>90 percent) will come from the global south. The two continents that will experience the greatest share of twenty-first-century urbanization are Asia and Africa - with India, China, and Nigeria accounting for over a third of all urban growth (UN 2014). Thus, the everyday reality of the twenty-first-century urban is, out of necessity, the focus on the cities of the global south. What does this mean for urban research, planning, and envisioning? We need a "southern sensibility" towards urbanization that takes in the reality that cities will increasingly become locations of contrasts. These "southern leanings" will include a focus on contrasts between informal and planned urban expansion; between local place-making and global teleconnections; between shanties and high-rise buildings; between urban sprawl and congested inner cities; between waste dumps and pristine restored parks; and of course, to the spaces of urban power that lie between states, business, criminals, and traditional powers. Urban reality now and in the immediate future will include deep social, ecological, economic, and technological rifts between cities as loci of upward mobility and as a wicked nexus of poverty, pollution, and powerlessness. The gradual realignment of the divisions between rich and poor within and between cities will spill beyond the life struggles for upward mobility and survival, drawing from the vitality of the urban planet. Urbanism in the global south will share certain generic features with their nineteenth-and twentiethcentury northern counterparts, but they will not copy or emulate them. What an 80 million inhabitant version of Dhaka will become, nobody really knows. What is the word for it? Is it a community, a region, a global subject? Or a concept yet to come? It is equally important to recognize that there is not a universal notion of cities of global south, as they exhibit as much disparity among themselves as when compared to those in the global north.

The challenge for mediating extremes absences and excesses in southern cities along the lines already claimed by northern urbanites is exacerbated by our absolute lack of knowledge and thus inability to put together dynamic analyses of urban change across most of the urbanizing world. In comparison to the vast amount of literature on cities in Europe, the Americas, and even China, we know relatively little about the southern cities, or their interactions with natural systems, in Congo, Pakistan, or Indonesia. This is further complicated by the extreme heterogeneity that characterizes the trajectories that different cities, large to small, have taken across different locations, as well as across different 
points in time. What is clear is that the growth of cities that lack planning capacity and local ecological expertise face problems. For instance, the semiarid Indian city of Bangalore, built to deal with droughts via an engineered system of rainwater harvesting via topographically interconnected tanks, now faces a perverse challenge of flooding in the monsoon season due to construction over water channels coupled with the ever-present challenge of drought in summer (Nagendra 2016). Kampala in Uganda faces iatropic challenges (events that necessitate medical care that are common to many southern cities) with technical interventions such as the establishment of sewage treatment plants (to deal with the city's burgeoning sewage problem), leading to perverse outcomes of biodiversity loss in rich wetlands, further reducing the city's capacity to naturally treat its sewage, and making it increasingly dependent on technical solutions (Lwasa 2010).

These experiences that reflect the interplay of urban systems are not unique to Bangalore and Kampala. They represent a wider problem: that formal approaches to city planning tend to prioritize technology and infrastructure provisioning and solutions, with the idea that social and ecological problems can be tackled later, by fitting piecemeal "solutions" onto an already engineered system. Yet experience tells us that this is impossible. Cities are also social-ecological systems, and the social, ecological, and indeed, cultural elements need to be designed with an explicit focus on multilevel, adaptive system design, integrated with technological aspects, from the start. For instance, recent research on food waste, a growing challenge in most southern cities, indicates that urban planning, transportation, and street design play a major role in shaping diets, food packaging, and energy usage in cities (Seto and Ramankutty 2016). The fact that the growth in most southern cities is yet to take place thus creates a formidable opportunity, one that helps us to take cognizance of the mistakes made in urban planning of the past, and move towards a new approach that is data based but which also takes into account the local cultural and ecological requirements of diverse locations and governance regimes to connect formal and informal planning, ideally achieving equitable city improvements by leapfrogging technology innovation and with planned, macroeconomic investment-heavy urban growth.

The global concentration of people suggests that challenges of the urban planet will be won or lost in cities of the global south, but only if action is swift (Figure 0.1). A comparison of the waves of globalization in the last two centuries with the earlier waves (Clark 2016) shows clearly that the duration of each wave is becoming shorter, in what we might think of as a great urban acceleration (McPhearson et al. 2016c). Where waves of change once lasted a century or more, they now appear to run their course in as little as 15 to 20 years, and in the future this duration may be even shorter. If the global economy becomes 

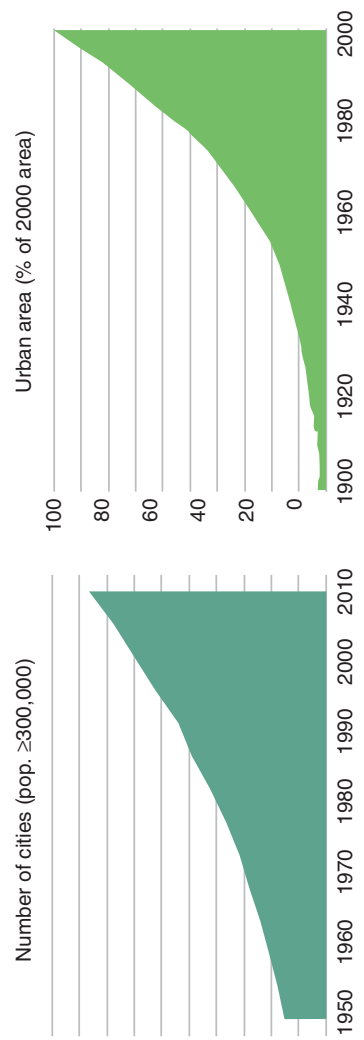

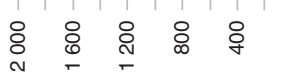

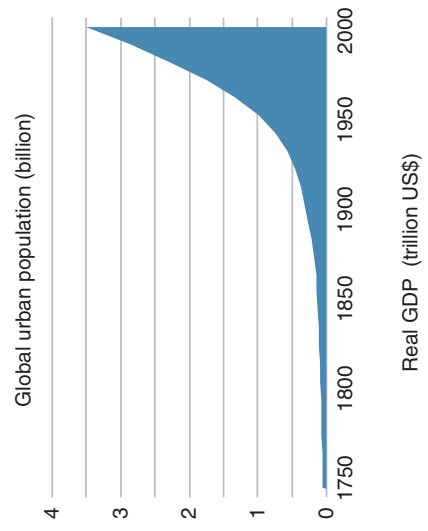

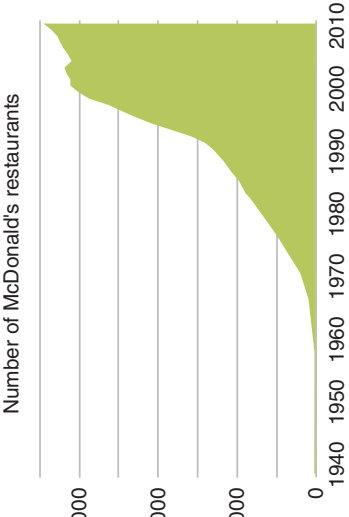

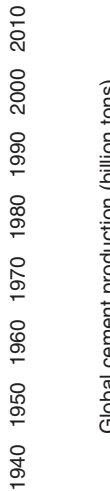
요음
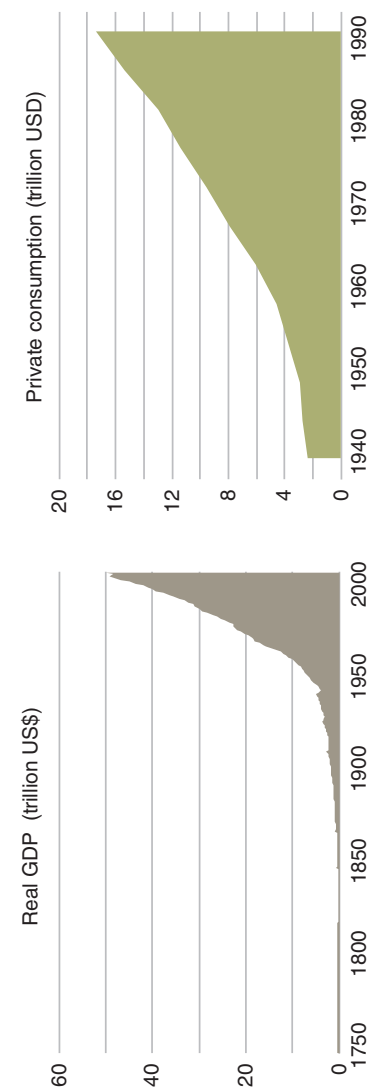

芩

3 ฮั 휴

ปั

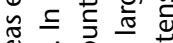

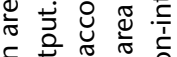

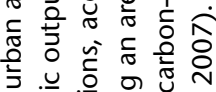

을

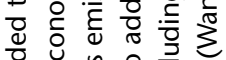

응 ฮั

용

응응 合 $\frac{0}{\sqrt{2}}$

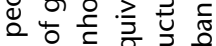

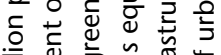

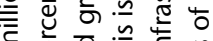

¿

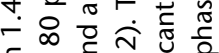

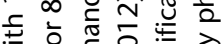

उ

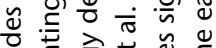

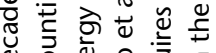

过 它 웡

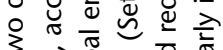

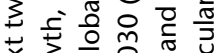

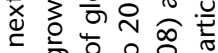

훙유융

융

远응 능 융

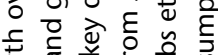

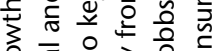

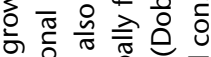

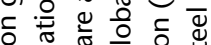

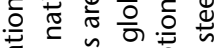

흔

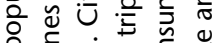

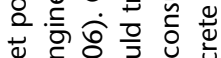

\& 8 o o o

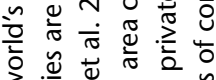

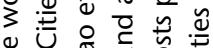

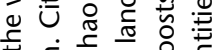

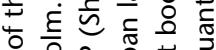

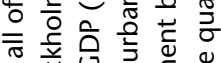

त

ते

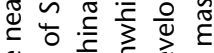

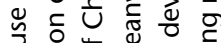

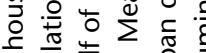

言 吾空

3ㅇㅁㅈㅊㅇㅇ 의

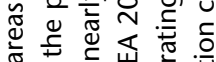

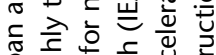

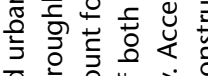

응 ठ

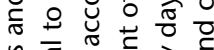

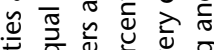

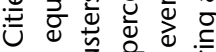

-

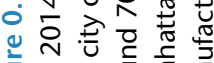

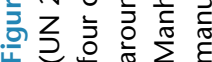


ever more integrated, globalizing city waves will increasingly come to resemble global economic cycles, and the windows of opportunity for cities to participate will close quickly.

Although there are vast differences between the networks of cities along the ancient silk roads and the twenty-first-century system of global value chains and competitive advantage, there are also striking parallels (Clark 2016). Today's cities can learn much from how those in previous waves built and sustained their competitive attributes, and how to avoid becoming locked into unsustainable or unproductive cycles of development. History shows this is a risk if cities lose competitiveness in traded sectors, fail to embrace innovation or to project influence, are closed to immigration and entrepreneurship, or are unable to adapt to a changing geopolitical or geo-economic center of gravity. The ingredients of today's most successful cities are sometimes hard for other cities to emulate directly, and so alternative strategies and pathways to global engagement have arisen. Over time, these alternative pathways result in very different kinds of global, or local and regional, cities.

\subsection{Knowledge for an Urban Planet}

The Urban Planet is full of provocations from artists, practitioners, and activists who remind us repeatedly that a bookish science of cities is not enough to change the hearts, minds, and actions of the millions of urban residents; they point out that generalization without authentication will never generate useful or legitimate knowledge. It is not easy to reconcile this unambiguous message with the equally stark assertion that scientists must be at the forefront of generating the evidence that underpins global urban reform; or that for science and scholarship to have the impact required at the necessary scale and pace, a massive expansion in research capacity and coverage is required. These are the competing, even contrasting imperatives of the knowledge spectrum that must inform the urban planet going forward. Clearly unlocking a more sustainable urban future will require more than a singular effort.

Locating cities in a global frame is by its nature a multiscalar exercise and necessitates an interdisciplinary and systems perspective - alongside approaches from nonsystemic and nomothetic fields such as the social sciences and the humanities. A global view on urbanism demands learning from past waves of globalization, understanding the reach and impact of technology (telecoms, renewables, etc.) on the individual and household as well as in the formation of worldwide city networks. The demand for new knowledge for this global urbanism does not negate old disciplinary contributions, but it demands the investigation of new places, greater urgency, and an understanding of 
complexity. A global view of the urban transition hopes to bring all cities into the picture through establishing major causal dynamics, fostering comparability, and acknowledging difference - these are demands that are the imperatives for new urban knowledge innovation.

The centrality of cities to the sustainability of people, the planet, and prosperity points to the need for continuous investments in an expanded and flexible urban science that is forged out of innovative interdisciplinary understandings of the complex systems that both drive and derive from the prevalence of urban ways of being (Parnell et al. 2017). This volume draws together nascent interdisciplinary and cross-stakeholder urban dialogues, with some contributors actively self-defining as part of a new urban science community and others presenting themselves as concerned thinkers or contributors to a more open-ended debate on the significance of the urban planet. While there are clearly incommensurate ideas evident across the chapters that follow, not least in the schism between scholar- and practitioner-produced texts, but all contributors to The Urban Planet share a commitment of generating new knowledge as an integral part of building a better urban future. Together we argue for greater understanding of specialist concerns, like water or air quality, and system-based analyses of the cities where we each live. Local understanding of general processes lies at the core of doing things better in cities, but case-based research is not enough. Large-scale interactions between urban life and the cultural, social, political, economic, and the ecological processes that we highlight in this book are all increasingly dominated by cities and require perspectives based on local knowledge alongside summative and trend assessments.

The contributions in this volume all, even when dealing with micro details, intersperse local reality and global exploration of the complex system relationships between nature and the city. Simultaneously tracking global trajectories and highlighting place- and issue-specific problems reveals the shortage of sophisticated analysis of the interactions across sectors and cities, and the absence of clear messaging from science to practice. Tracking the surges of urbanization globally, we pose two overarching questions. First, what new thinking and evidence is required to radically shift the urban trajectory onto a more sustainable path. Second how, using evidence drawn in different ways and from cities across the world, can we reimagine and motivate for the changes that are required to implement the alternative global urban agenda. There has already been some success in the new urban endeavor - the call for a city-centric change to how we understand and regulate the world, which was endorsed by the 2030 Agenda in 2015 (UN 2015), was underpinned by the work of scientists. The approval of an urban Sustainable Development Goal and a number of other multilateral agreements to put cities at the core of global development has since confirmed the collective acceptance of the importance 
of the city to global environmental change. The immediate aftermath of the radical pro-city realignment of global policy scientists welcomed the role that evidence had played in securing global policy realignment (Barnett and Parnell 2016), but note, too, the imperative of ensuring ongoing evidence-led multilateral action in amending policy direction and monitoring implementation of urban sustainable development objectives. In addition, both individual scholars and organized science have endorsed very different modes of knowledge production: The new urban science has aspirations to inter- and transdisciplinarity and to coproduction.

As we highlight in the concluding chapter, substantive methodological and philosophical challenges remain in placing the study of cities in the crosshairs of sometimes-conflicting disciplinary rationalities. Similarly, the demands of integrating the ideas of non academic voices into the scientific text should not be underestimated. Notwithstanding these challenges, the imperative for a new science of cities and cogenerating knowledge across scholars, artists, residents, and practitioners remains an aspiration we endorse and have sought to pursue in The Urban Planet, even while we are aware of the different registers and even dissonant voices that this approach creates. Taken together, the book's contents, from right across the multidisciplinary and artist-practitioner-activist-scholar spectrum, all affirm the multilateral demand that cities be given greater prominence in global development in ways that reflect the geographical complexity and range of city realities. The Urban Planet highlights the multiple, even competing, concerns of what we may frame as existing or contemporary urban theory, but we are unambiguous of the need to put cities in the foreground of knowledge production and informed, responsible policy-making.

In reformulating and extending urban knowledge to meet the policy ambitions of cities, nations, and the multilateral system, a more extensive and robust urban science has to better address urban complexity and difference. The new knowledge outputs will also need to be legible so that evidence and analysis can more effectively guide (and evaluate) urban decision-makers in the critical decades ahead. There is a clear political and practical imperative in coming to terms with the universal challenges and opportunities embodied in the dynamics of the urban transition. Nuanced locally specific study is clearly imperative to inform action, and no two cities are the same. But, a common global urban register or vision that is understood by a range of stakeholders is what will change mindsets and galvanize collective action at the scale required to ensure a more sustainable urban planet. The intellectual challenge is thus a task of informing, critiquing, and revising the methods and modes of urban thinking - to collectively improve urban life for all. Doing this requires not only working with varied stakeholders but also coming to grips with missing 
data and complex urban dynamics. No single discipline or scholar or laboratory can achieve this alone - not least as there is a critical need to incorporate many more urban points into the overall theorizing of the city. Collaboration is essential.

Finally, divergent views are inevitable in building cross-disciplinary multi-stakeholder pathways for an ever-more urbanized age ahead. While consensus is unlikely (and may not be desirable) it should be possible to identify, based on robust research, the major issues facing the urban planet. To this end, there are four overarching intellectual tensions that inform this volume.

- First is the idea that while the Anthropocene already entails a fundamentally urban way of life and urban identity (Ljungqvist et al. 2010; Barthel et al. 2010), biophysical impact is not the only respect in which cities will shape the future - far from it.

- Second is that while specialist knowledge needs to be valued and extended, there is an imperative for new forms of urban knowledge, where cities are located in a global framing and approached from an interdisciplinary and systems perspective.

- Third is that although twenty-first-century urbanism requires a particular focus on the global south, all cities and regions can and must innovate to transform from their currently unsustainable trajectories.

- Fourth is that at the same time that researchers have to maintain critical independent views, the present is a critical time for urban scholars and policy-makers to work together to achieve the major transitions and transformations that are needed.

\section{References}

Acuto, M., and Parnell, S. (2016). Leave No City Behind, Nature, 352(6288): 873.

Bai, X., McPhearson, T., Cleugh, H., Nagendra, H., Tong, X., Zhu, T., and Zhu, Y.G. (2017). Understanding Urban-Environmental Linkages: Conceptual and Empirical Advances, Annual Review of Environment and Resources, 42(1): 215-240.

Barnett, C., and Parnell, S. (2016) Ideas, Implementation and Indicators: Epistemologies of The post-2015 Urban Agenda, Environment and Urbanization, 28(1): 87-98.

Barthel, S., Sörlin, S., and Ljungkvist, J. (2010). Innovative Memory and Resilient Cities: Echoes from Ancient Constantinople, in Sinclair, P., Nordquist, G., Herschend, F., and Isendahl, C. (eds.), The Urban Mind: Cultural and Environmental Dynamics, Uppsala: Uppsala University, pp. 391-405.

Batty, M. (2013). The New Science of Cities, Cambridge, MA: MIT Press. 
Biermann, F., Bai, X., Bondre, N., Broadgate, W., Chen, C.T.A., Dube, O.P., Erisman, J.W., Glaser, M., van der Hel, S., Lemos, M.C., and Seitzinger, S. (2016). Down to Earth: Contextualizing the Anthropocene. Global Environmental Change, 39: 341-350.

Braun, B. (2005). Environmental Issues: Writing a More-than-Human Urban Geography, Progress in Human Geography, 29 (5): 635-650.

Brenner, N., and Schmid, C. (2014). Planetary Urbanization, in Brenner, N. (ed.) Implosions/ Explosions: Toward a Study of Planetary Urbanization. Berlin: Jovis, pp. 160-163.

Clark, G., (2016). Global Cities: A Short History. Washington, DC: Brookings Institution Press.

Schaer, F. (2012). Urban World: Cities and the Rise of the Consuming Class. New York: McKinsey Global Institute.

Elmqvist, T., Redman, C. L., Barthel, S., and Costanza, R. 2013. History of Urbanization and the Missing Ecology, in, Elmqvist, T., Bai, X., Frantzeskaki, N., Griffith, C., Maddox, D., McPhearson, T., et al. (eds.), Urbanization, Biodiversity and Ecosystem Services: Challenges and Opportunities. The Netherlands: Springer Open, pp.13-30. DOI 10.1007/978-94-007-7088-1_2. Erixon Aalto, H., and Ernstson, H. (2017). Of Plants, High Lines and Horses: Civics and Designers in the Relational Articulation of Values of Urban Natures. Landscape and Urban Planning, 157: 309-321.

Ernstson, H., Lawhon, M., and Duminy, J. (2014) Conceptual Vectors of African Urbanism: "Engaged Theory-Making" and "Platforms of Engagement." Regional Studies, 48 (9): 1563-1577.

Ernstson, H., and Sörlin, S. (eds.) (2018). Grounding Urban Natures: Histories and Futures of Urban Ecologies, Cambridge, MA: MIT Press, in review.

Florida, R. (2002) The Rise of the Creative Class. New York: Basic Books.

Gandy, M., (2013) Marginalia: Aesthetics, Ecology, and Urban Wastelands, Annals of the Association of American Geographers, 103 (6): 1301-1316.

Glaeser, E. (2011). Triumph of the City: How Our Greatest Invention Makes Us Richer, Smarter, Greener, Healthier, and Happier. Harmondsworth: Penguin.

Lachmund, J. (2011). The Making of an Urban Ecology. Biological Expertise and Wildlife Preservation in West Berlin, in Brantz, D., and Dümpelmann, S. (eds.), Greening the City. Urban Landscapes in the Twentieth Century. Charlottesville/London: University of Virginia Press, pp. 204-227.

Heynen, N.C., Kaika, M., and Swyngedouw, E. eds., (2006). In the Nature of Cities: Urban Political Ecology and the Politics of Urban Metabolism (Vol. 3), London: Taylor \& Francis.

Heynen, N., (2014) Urban Political Ecology I: The Urban Century, Progress in Human Geography, 38 (4): 598-604.

Hinchliffe, S., and Whatmore, S., (2006) Living Cities: Towards a Politics of Conviviality, Science as Culture, 15 (2): 123-138.

Hinchliffe, S., (2008) Reconstituting Nature Conservation: Towards a Careful Political Ecology, Geoforum, 39 (1): 88-97.

Hodson, R. (2016) Urban Health and Well-Being, Nature, 531: 7594.

International Energy Agency (IEA), 2008. World Energy Outlook 2008. Paris: International Energy Agency. 
Ljungkvist, J., Barthel, S., Finnveden, G., and Sörlin, S. (2010). The Urban Anthropocene: Lessons for Sustainability from the Environmental History of Constantinople, in Sinclair, P.J.J., Nordquist, G., Herschend, F., and Isendahl, C. (eds.), The Urban Mind: Cultural and Environmental Dynamics. Uppsala University: Department of Archaeology and Ancient History, pp. 367-390.

Lwasa, S. (2010). Adapting Urban Areas in Africa to Climate Change: The Case of Kampala, Current Opinion in Environmental Sustainability, 2(3): 166-171.

McPhearson, T., Pickett, S.T.A., Grimm, N., Niemelä, J., Alberti, M., Elmqvist, T., et al. (2016). Advancing Urban Ecology Toward a Science of Cities, BioScience, 66(3):198-212.

McPhearson, T., Parnell, S., Simon, D., Gaffney, O., Elmqvist, T., Bai, X., et al. (2016b) Scientists Must Have a Say in the Future of Cities, Nature, 538: 165-166.

McPhearson, T., Parnell, S., Simon, D., Gaffney, O., Elmqvist, T., Bai, X., et al. (2016c). Building Urban Science to Achieve the New Urban Agenda, The Nature of Cities, www.thenatureofcities .com/2016/10/24/building-urban-science-to-achieve-the-new-urban-agenda/

Melosi, M.V. (1993) The Place of the City in Environmental History, Environmental History Review, 17: $1-23$.

Melosi, M.V. (2010) Humans, Cities, and Nature: How Do Cities Fit in the Material World?, Journal of Urban History, 36 (1): 3-21.

Mitlin, D., and Satterthwaite, D. (2013) Urban Poverty in the Global South: Scale and Nature. London: Routledge.

Nagendra, H. (2016) Nature in the City: Bengaluru in the Past, Present and Future. New Delhi: Oxford University Press.

Parnell, S., and Robinson, J. (2017). The Global Urban: Difference and Complexity in Urban Studies and the Science of Cities, in Hall, S., and Burdett, R. (eds.) Handbook of Social Science. London: Routledge, pp. 13-31.

Robinson, J. (2016). Thinking Cities through Elsewhere: Comparative Tactics for a More Global Urban Studies, Progress in Human Geography, 40(1): 3-29.

Rosen, C., and Tarr, J. (1994) The Importance of an Urban Perspective in Environmental History, Urban History, 20: 299-310.

Rosenzweig, C., Solecki, W., Hammer, S.A., and Mehrotra, S. (2010). Cities Lead the Way in ClimateChange Action, Nature, 467(7318): 909-911.

Sedrez, Lise. (2005). The "Bay of All Beauties": State and Environment in Guanabara Bay, Rio de Janeiro, Brazil, 1875-1975. Ann Arbor, MI: University Microfilms.

Seto, K., Güneralp, B., and Hutyra, L. (2012). Global Forecasts of Urban Expansion to 2030 and Direct Impacts on Biodiversity and Carbon Pools, Proceedings of the National Academy of Sciences, 109: $16083-16088$.

Seto, K.C., and Ramankutty, N. (2016). Hidden Linkages between Urbanization and Food Systems. Science, 352: 943-945.

Sharan, A. (2014). In the City, Out of Place: Nuisance, Pollution and Urban Dwelling in Modern Delhi, c.1850-2000. Oxford: Oxford University Press.

Shao, M., Tang, T., Zhang, Y., and Li, W. (2006) City Clusters in China: Air And Surface Water Pollution, Frontiers of Ecology and the Environment, 4: 353-361. 
Simon, D. (ed.) (2016). Rethinking Sustainable Cities: Accessible, Green and Fair. Bristol: Policy Press. Sukopp, H. (2002). On the Early History of Urban Ecology in Europe. Preslia, Praha 74: 373-393.

Swyngedouw, E. (1996). The City as a Hybrid: On Nature, Society and Cyborg Urbanization, Capitalism Nature Socialism, 7 (2): 65-80.

Swyngedouw, E. (2004). Social Power and the Urbanization of Water: Flows of Power. Oxford: Oxford University Press.

United Nations (2014). World Urbanization Prospects: The 2014 Revision, New York: United Nations Department of Economic and Social Affairs.

United Nations (2015) Transforming Our World: The 2030 Agenda for Sustainable Development. New York: United Nations.

Warren-Rhodes, K., and Koenig, A. (2001). Escalating Trends in the Urban Metabolism of Hong Kong: 1971-1997, AMBIO: A Journal of the Human Environment, 30(7): 429-438.

Wang, T., Müller, D.B., and Graedel, T.E. (2007) Forging the Anthropogenic Iron Cycle. Environmental Science \& Technology 41(14): 5120-5129.

Watson, V. (2009) Seeing from the South: Refocusing Urban Planning on the Globe's Central Urban Issues, Urban Studies, 46: 2259-2275.

Zalasiewicz, J., et al. (2017). Scale and Diversity of the Physical Technosphere: A Geological Perspective, Anthropocene Review, 4(1): 9-22. 